\title{
SCIDic
}

International Journal of Clinical Dermatology \& Research (IJCDR)

ISSN: 2332-2977

\section{Serum Trace Element Levels in Patients with Alopecia Areata}

Nadia A. El Sherif ${ }^{*}$, Salwa A. El-Dibany²

${ }^{1}$ Dermatology Department, Benghazi university, Faculty of Medicine, Benghazi.

${ }^{2}$ Dermatology Department, Omar El-Mukhtar University, Al-Beida, Libya.

\section{Abstract}

Background: Alopecia areata is a disease characterized by focally, non-scarring hair loss on the scalp or any hair-bearing surface. The etiology is unknown, although the evidence suggests that AA is an immunologically mediated disease. Trace elements are essential cofactors for multiple enzymes and have a role in important functional activities within the hair follicle.

Objective: The aim of our study was to evaluate serum concentrations ofcopper $(\mathrm{Cu})$, zinc $(\mathrm{Zn})$, magnesium $(\mathrm{Mg})$, iron $(\mathrm{Fe})$, folate and blood hemoglobin $(\mathrm{Hb})$ in patients with $\mathrm{AA}$ and healthy subjects. We also examined a possible association between serum levels of TE and the clinical types, durationand family history of AA.

Patients \&Methods: The serum levels of TE were measured in 42 patients with AA and 50 age and sex matched healthy controls. According to the clinical type of AA, patients were divided into 2 groups: patients with single patch of hair loss (alopecia unilocularis, AU), or with multiple patches (alopecia multilocularis, AM).

Results: Serum levels of $\mathrm{Cu}$ and $\mathrm{Zn}$ were significantly lower in patients as compare to control subjects $(\mathrm{P}=.000)$, serum $\mathrm{Mg}$ were significantly increased $(\mathrm{P}=.000)$. While $\mathrm{Hb}$ show no difference between patients and control subjects, serum $\mathrm{Fe}$ and folate both were insignificantly decreased in patients with AA. Patients with AU had significantly lower serum $\mathrm{Zn}$ and $\mathrm{Cu}$ $(\mathrm{P}=.000)$, whereas, serum $\mathrm{Mg}, \mathrm{Fe}$, folate and $\mathrm{Hb}$ show no significant difference $(\mathrm{P}>0.05)$ compare to patients with AM.No correlations were found between gender, family history of AA, duration of the disease, and serum levels of TE.

Conclusion: Present study suggests that low serum levels of zinc and copper seem to be an important risk factors for AA.

Keywords: Alopecia Areata; Trace Elements; Unilocularis; Multilocularis.

\section{Introduction}

Alopecia areata (AA) is an organ-specific autoimmune disorder that targets anagen phase hair follicles. It has an unpredictable chronic-relapsing course, leading to transient non-scarring hair loss. Clinically, presentations vary considerably between individuals, ranging from small patches of alopecia to the loss of all body hair; alopecia universalis [1].

Prevalence of AA has been estimated to about $0.2 \%$ of the general population. AA can start at any age, however in the majority of patients, the onset is within the first three decades of life. There is none race or sex predilection. AA is often associated with other autoimmune diseases that must be investigated [1].

In most patients, disease severity is closely correlated with psy- chological distress, and management of AA should include psychological support. The course of AAis not predictable, as spontaneous remission is possible, as well as a chronic course not responding to therapy [2].

Trace elements are essential cofactors for multiple enzymes and have important functional activities within hair follicles [3]. They perform various catalytic, structural and regulatory functions of our body [4]. The trace elements such as zinc and copper have much important role in the growth and development of hair [3]. There are many studies claim that imbalance of trace elements may trigger AA [4].

\section{Objective of the Study}

To evaluate serum concentrations of copper $(\mathrm{Cu})$, zinc $(\mathrm{Zn})$, mag-

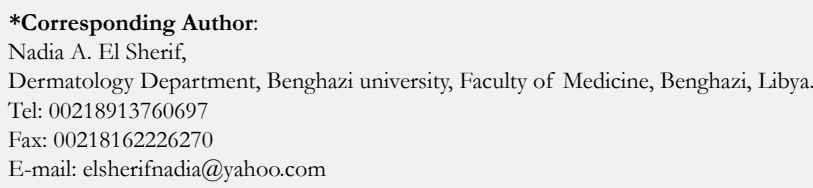

Copyright: Nadia A. El Sherif 2020 . This is an open-access article distributed under the terms of the Creative Commons Attribution License, which permits unrestricted use, distribution and reproduction in any medium, provided the original author and source are credited. 
nesium $(\mathrm{Mg})$, iron $(\mathrm{Fe})$, folate and blood hemoglobin $(\mathrm{Hb})$ in patients with AA and healthy subjects.

To examined a possible association between serum levels of TEwith clinical types, duration and family history of AA.

\section{Patients and Methods}

The study included 42 patients with a diagnosis of patchy AArecruited from the OPD of Dermatology Department at El-Jumhoria hospital in Benghazi city, Libya. Patients with alopecia totals, alopecia universalis, as well as patients with any autoimmune skin or systemic diseases were excluded from the study. According to the clinical type of AA, patients were divided into 2 groups: patients with single patch of AA; alopecia Unilocularis (AU), and patients with multiple patches; alopecia multilocularis (AM). According to the duration of disease, the patients were divided into 2 groups: duration of 1 year or less, and more than 1 year. The control group consisted of 50 sex and age matched healthy subjects. Blood sample was taken from each patient and control subject for measurement of serum levels of $\mathrm{Zn}, \mathrm{Cu}, \mathrm{Mg}, \mathrm{Fe}$, folate and $\mathrm{Hb}$. A signed consent was obtained from all patients and subjects after explaining the nature of the study to them and manuscript is according to declaration of Helsinki.

\section{Statistical Analysis}

All statistical analyses were performed using SPSS software for Windows (Version 16.0). Results are presented as mean \pm standard deviations for continuous variables and as a number (\%) for categorical variables. The Chi-square testand independent t-test were used for statistical analysis. Differences were considered as statistically significant with $\mathrm{P}$ values $<0.05$.

\section{Results}

Table 1. Show the demographic data of patients under study and control subjects. In the total of 42 patients with $\mathrm{AA}$, there were $14(33.3 \%)$ patients with AU, 28 (66.7\%) patients with AM.

Serum levels of $\mathrm{Cu}$ and $\mathrm{Zn}$ were significantly lower in patients as compare to control subjects $(\mathrm{P}=.000)$, serum $\mathrm{Mg}$ were significantly increased $(\mathrm{P}=.000)$. While $\mathrm{Hb}$ show no difference between patients and control subjects, serum $\mathrm{Fe}$ and folate both were insignificantly decreased $(\mathrm{P}>0.05)$ in patients with AA (Table 2). According to clinical type patients with AM had significantly lower serum $\mathrm{Zn}$ and $\mathrm{Cu}(\mathrm{P}=.000)$, as compare to $\mathrm{AU}$ patients. Whereas, serum $\mathrm{Mg}, \mathrm{Fe}$, folate and $\mathrm{Hb}$ show no significant difference $(\mathrm{P}>0.05)$ (Table 3). No correlations were found between gender, family history of $\mathrm{AA}$ and duration of the disease, and

Table 1. The demographic data of Alopecia areata patients under study.

\begin{tabular}{|c|c|c|c|}
\hline Demographic data & AA patients (42) & Control subjects (50) & P value \\
\hline Age mean \pm SD yrs & $29.3 \pm 7$ yrs & $32 \pm 10 \mathrm{yrs}$ & 0.117 \\
\hline Sex & & \multicolumn{2}{|l}{} \\
\hline Female & $18(43 \%)$ & $27(54 \%)$ & \multirow{2}{*}{0.196} \\
\hline Male & $24(57 \%)$ & $23(46 \%)$ & \\
\hline Duration yrs \pm SD & $2.3 \pm 1.6$ yrs & NA & \\
\cline { 1 - 3 } Clinical type & \multicolumn{3}{|l}{} \\
\hline Unilocularis & $14(33.3 \%)$ & NA & \\
\hline Multilocularis & $28(66.7 \%)$ & \multicolumn{2}{|l}{} \\
\hline
\end{tabular}

Table 2. Mean of serum levels of TE in AA patients and control subjects.

\begin{tabular}{|c|c|c|c|}
\hline Serum level & $\begin{array}{c}\text { AA patients } \\
\text { Mean } \pm \text { SD }\end{array}$ & $\begin{array}{c}\text { Control subjects } \\
\text { Mean } \pm \text { SD }\end{array}$ & P value \\
\hline Hemoglobin $(\mathrm{g} / \mathrm{dl})$ & $12.8 \pm 2$ & $12.7 \pm 2$ & 0.684 \\
\hline Iron $(\mu \mathrm{g} / \mathrm{dl})$ & $110 \pm 45$ & $117 \pm 32$ & 0.41 \\
\hline Copper $(\mu \mathrm{g} / \mathrm{dl})$ & $106 \pm 14$ & $156 \pm 43$ & $.000^{*}$ \\
\hline Zinc $(\mu \mathrm{g} / \mathrm{dl})$ & $77 \pm 12$ & $90.2 \pm 18.9$ & $.000^{*}$ \\
\hline Magnesium $(\mathrm{mg} / \mathrm{dl})$ & $2.2 \pm .5$ & $1.9 \pm .2$ & $.000^{*}$ \\
\hline Folate $(\mathrm{ng} / \mathrm{ml})$ & $7.8 \pm 4$ & $9.5 \pm 5$ & 0.093 \\
\hline
\end{tabular}

Table 3. Correlation between the extension of AA and other variables.

\begin{tabular}{|c|c|c|c|}
\hline Serum level & Alopecia Unilocularis & Alopecia Multilocularis & P value \\
\hline Hemoglobin $(\mathrm{g} / \mathrm{dl})$ & $12.7 \pm 2$ & $13.2 \pm 2$ & 0.482 \\
\hline Folate $(\mathrm{ng} / \mathrm{ml})$ & $8 \pm 5$ & $7 \pm 3.3$ & 0.272 \\
\hline Zinc $(\mu \mathrm{g} / \mathrm{dl})$ & $81 \pm 11$ & $68.4 \pm 10$ & $.000^{*}$ \\
\hline Copper $(\mu \mathrm{g} / \mathrm{dl})$ & $111 \pm 12$ & $96 \pm 9$ & $.000^{*}$ \\
\hline Magnesium $(\mathrm{mg} / \mathrm{dl})$ & $2.2 \pm .5$ & $2.2 \pm .5$ & 0.932 \\
\hline Iron $(\mu \mathrm{g} / \mathrm{dl})$ & $111 \pm 46$ & $108 \pm 45$ & 0.706 \\
\hline
\end{tabular}


serum levels of TE.

\section{Discussion}

Alopecia areata is a common immune-mediated condition characterized by non-scarring hair loss. Lifetime incidence of AA ranges from $1.7 \%-2.1 \%$, with higher prevalence in younger patients but no significant difference in incidence exists between males and females [5]. AA can have profound effects on patient's quality of life [1].

Trace elements, which though required in only minute amounts, have a physiological function as enzyme cofactors, biologic substrates, and even as hormones [6]. Physical properties of the hair, their shape, color, thickness, elasticity, growth rate depend on the microelement composition [6]. Moreover, trace elements are essential cofactors for multiple enzymes and have a role in important functional activities within the hair follicle [7]. Furthermore, some micro nutrients reduce oxidative stress, an increasingly suspected contributor to AA pathogenesis [7].

$\mathrm{Zn}$ and $\mathrm{Cu}$ are an essential trace elements required for functional activities in hair follicle and help in hair follicle recovery [6]. Many studies speculated that a copper/zinc imbalance might play a role in AA pathogenesis through an imbalance in oxidant/antioxidant activity [8]. $\mathrm{Zn}$ and $\mathrm{Cu}$ required for the function of many enzymes like; alkaline phosphatase which has elevated activity in hair follicle, and copper/zinc superoxide dismutase which is potent antioxidant [8]. Moreover, deficiency of Zn impairs DNA and RNA production which is required for the normal division of hair follicle cells and developmental stage of hair growth [9].

In the present study, mean serum $\mathrm{Zn}$ and $\mathrm{Cu}$ were significantly lower in patients with AA than that of controls, Our results are in agreement with previous studies which reported lower serum levels of $\mathrm{Zn}$ and $\mathrm{Cu}$ in their patients with $\mathrm{AA}[4,8-12]$.

Naginiene et al., reported a lower level of zinc in blood and urine of children with alopecia and increased levels of copper and chromium concentrations in their hair compared to healthy individuals [13], however, other studies did not find any difference in serum $\mathrm{Zn}$ and $\mathrm{Cu}$ levels of AA patients versus controls [3, 6, 7, 14].

In the present study patients with AM had significantly lower serum $\mathrm{Zn}$ and $\mathrm{Cu}$ as compare to patients with $\mathrm{AU}$, this was in agreement with study of Abdel Fattah et al., who reported an inverse correlation between serum zinc levels and severity of AA [8]. No correlations were found between duration of the disease and serum levels of $\mathrm{Zn}$ and $\mathrm{Cu}$, inconsistent with previous study which reported an inverse correlation between serum zinc levels and duration of AA [8].

Magnesium acts as a cofactor for over 300 enzyme systems, and plays an important role in nucleotide synthesis, a frequent process in the rapidly dividing hair follicle [15]. A small number of studies have investigated the serum levels of $\mathrm{Mg}$ in AA. Serum $\mathrm{Mg}$ levels in patients with AAunder study were significantly higher than that of control subjects. Our result was in agreement with study of Bruske et al, who found a significantly higher level of Mgin serum of AA patients [16]. However, previous studies reported insignificant rise in serum $\mathrm{Mg}$ in $\mathrm{AA}$ patients as compared to controls subjects $[7,17]$.

Iron deficiency has been suggested toplay a role in AA, but its effect is controversial. Patients under study show insignificantly decreased serum $\mathrm{Fe}$ while blood $\mathrm{Hb}$ show no difference as compare to control subjects, the result is in agreement with previous studies $[3,18]$. However, Esfandiarpour et al., found a higher mean level of serum iron and ferritinand a lower mean level of TIBC in AA patients compared to the control subjects, but this differences was statistically insignificance [19].

Iron deficiency remains the most common nutritional deficiency in the world. Iron serves as a cofactor for ribonucleotide reductase, the rate-limiting enzyme in DNA synthesis. Therefore, iron exhibits an important role in tissues with high cellular turnover, like the hair follicle matrix [15].

Serum folate of the patients under study was insignificantly lower as compare to control subjects, in agreement with study of Goul et al., [18]. Moreover, previous study reported significant lower levels of RBC folate in alopecia totalis/alopecia universalis patients compared to the patients with patchy hair loss [20].

\section{Conclusion}

Present study suggests that low serum levels of zinc and copper seem to be an important risk factors for AA especially with more extensive disease.Routine serum testing of these elements and therapeutic supplementation can be recommended for AA patients.

\section{References}

[1]. Hordinsky MK. Overview of alopecia areata. J InvestigDermatolSymp Proc. 2013;16:13-5. PMID: 24326541.

[2]. Messenger AG, McKillop J, Farrant P, McDonagh AJ, Sladden M. British Association of Dermatologists' guidelines for the management of alopecia areata 2012. Br J Dermatol. 2012;166:916-26. PMID: 22524397.

[3]. Dastgheib L, Mostafavi-Pour Z, Abdoraazagh AA, Khoshdel Z, Sadati MS, Ahrari I, et al.Comparison of $\mathrm{Zn}, \mathrm{Cu}$ and $\mathrm{Fe}$ content in hair and serum in alopecia areata patients with normal group. Dermatol Res and pract.2014; 2014:784863. PMID: 25246935.

[4]. El-Ashmawy AA, Khedr AM. Some trace elements level in alopecia areata. Egypt Dermatol Online J. 2013; 9(1): 6.

[5]. Villasante Fricke AC, Miteva M. Epidemiology and burden of alopecia areata: a systematic review. ClinCosmetInvestigDermatol. 2015; 8:397-403. PMID: 26244028

[6]. Kil MS, Kim CW, Kim SS. Analysis of serum zinc and copper concentrations in hair loss. Ann Dermatol. 2013; 25 (4): 405-09. PMID: 24371385.

[7]. Bhat YJ, Manzoor S, Khan AR, Qayooni S. Trace element levels in alopecia areata. Indian J. Dermatol. Venereol. Leprol. 2009;75:29-31. PMID: 19172027.

[8]. Abdel Fattah NS, Atef MM, Al-Qaradaghi SM.Evaluation of serum zinc level in patients with newly diagnosed and resistant alopecia areata.Int J Dermatol. 2016;55:24-9. PMID: 26147750.

[9]. Rahman F, Akhter QS. Serum Zinc and Copper Levels in Alopecia J Bangladesh Soc Physiol. 2019;14(1): 21-25.

[10]. Lee SY, Nam KS, Seo YW, Lee SJ, Chung H. Analysis of serum zinc and copper levels in alopecia areata. Ann of Dermatol. 1997; 9(4): 239-41.

[11]. Hamad WAM, Said AF, El Hamid AAA.Role of some trace elements in the pathogenesis of telogeneffluvium in Egyptian female. Egypt Women Dermatol Soc. 2010; 7: 44-48.

[12]. Amirnia M, Sinafar S, Sinafar H, Nuri M. Assessment of Zinc and Copper Contents in the Hair and Serum and Also Superoxide Dismutase, Glutathion Peroxidase and Malondi Aldehyde in Serum in Androgenetic Alopecia and Alopecia Areata. Life Science Journal. 2013; 10:204-209.

[13]. Naginiene R, Kregzdyte R, Abdrakhmanovas A, Ryselis S. Assay of trace elements, thyroid gland and blood indices in children with alopecia. Trace 
Elements and Electrolytes. 2004;21:207-210.

[14]. Mussalo-Rauhamaa H, Lakomaa EL, Kianto U, Lehto J. Element concentrations in serum, erythrocytes, hair and urine of alopecia patients. ActaDermVenereol. 1986; 66:103-109.

[15]. Thompson JM, Mirza MA, Park MK, Qureshi AA, Cho E. The Role of Micronutrients in Alopecia Areata: A Review. Am J ClinDermatol. 2017;18(5):663-679. PMID: 28508256.

[16]. Bruske K, Salfeld K. Zinc and its status in some dermatological diseases: A statistical assessment. Z Hautkr.1987;62:125-31. PMID: 3442079.

[17]. Jin W, Zheng H, Shan B, Wu Y.Changes of serum trace elements level in patients with alopecia areata: Ameta-analysis. J Dermatol. 2017;44:588-591.
PMID: 28150385.

[18]. Gonul M, Cakmak SK, Soylu S, Kilic A, Gul U. Serum vitamin B12, folate, ferritin, and iron levels in Turkish patients with alopecia areata. Indian J DermatolVenereolLeprol. 2009;75:552. PMID: 19736464.

[19]. Esfandiarpour I, Farajzadeh S, Abbaszadeh M. Evaluation of serum iron and ferritin levels in alopecia areata.Dermatol Online J. 2008 Mar 15;14(3):21 PMI: 18627722.

[20]. Yousefi M, Namazi MR, Rahimi H, Younespour S, Ehsani AH, Shakoei S. Evaluation of Serum Homocysteine, High-Sensitivity CRP, and RBC Folate in Patients with Alopecia Areata. Indian J Dermatol. 2014;59(6):630. PMID: 25484412. 